\title{
Research on the Construction of Financial Support System for Small and Micro Enterprises (SME) in China
}

\author{
Li Pingnv \\ $\mathrm{Xi}$ 'an Fanyi University
}

\begin{abstract}
Small and micro enterprises(SME) are the main body of national economic organization, which play an irreplaceable role in promoting economic growth, expanding employment, increasing tax revenue and promoting social stability. The necessary capital investment is an important guarantee for enterprise development, but at present, the financing of SME accounts for less than half of the total social financing scale, which seriously restricts the development of SME and the national economy. This paper aims to make a breakthrough in the financing dilemma of SME. Based on the analysis on the two major causes of the financing difficulties of SME and the current status of the financial support system, this paper explores and studies the construction of the financial support system of SME.
\end{abstract} system

Keywords-SME; Enterprise financing; Financial support

\section{INTRODUCTION}

With the steady growth of national economy and the rapid development of e-commerce, China's SME are in a good development environment and broad development space. It is estimated that in 2020, the market size of medium-sized enterprises in China will reach 66 trillion yuan, the market size of small enterprises will reach 90 trillion yuan, and the market size of SME will account for over $90 \%$, according to the survey and consultation report of China's SME 2018. As the market subject and the cornerstone of social and economic development, SME have been trapped in financing problems for a long time in their development process. Building a financial support system for SME will not only help the development of enterprises themselves, but also be an important engine and strong guarantee for social and economic development.

\section{ANALYSIS ON THE ROOT CAUSE OF FINANCING DIFFICULTIES OF SME}

\section{A. Defects in the financial system}

1) Imbalance of financial institution structure. At present, commercial Banks are the main body in the system structure of China's financial institutions, and the indirect financial model with Banks as intermediary is the main financing mode in China. Among them, large commercial Banks (industrial and commercial bank of China, agricultural bank of China, bank of China, construction bank and bank of communications) play an absolutely important role in China's banking industry. Their assets account for nearly half of the total assets of the banking industry, and they are the main source of financing for enterprises, institutions and individual customers. On the one hand, peer based on big companies and big Banks, market status, large scale, financial system complete, full of the mortgaged property, and has strong solvency, capital demand equal the combined flow of multiple small business capital demand, so the Banks prefer to provide financing services for large enterprises, in order to reduce the unit cost of loans, strive for profit maximization. On the other hand, due to the small size of small enterprises, lack of collateral, low credit rating, poor debt paying ability and small tolerance of economic fluctuation risk, commercial Banks and small enterprises need to take more risks in credit business, but can only obtain less profits[9]. Therefore, as the ultimate goal of profit maximization, all commercial Banks prefer to carry out credit business for large enterprises with low risks and high profits, while many SME have suffered from "crowding out effect"[6].

2) Unreasonable allocation of credit resources. Due to the serious irrationality of the hierarchical structure of China's financial system for quite a long period, large Banks have mastered a large amount of credit resources and basically monopolized the social financing channels, while the small and medium-sized financial institutions have not been fully developed and formed the characteristics of "seller's market" in China's financial market. According to statistics, by the end of 2017, the market share of loans from the five major Banks of "" industrial, agricultural, medium, construction and delivery" "reached 44.30 percent of the total loan amount. As the largest city commercial bank, Beijing bank's loan amount is only $1 / 17$ of that of industrial and commercial bank of China[12]. Excessive credit resources are concentrated in large banking 
financial institutions, and small and medium-sized financial institutions have relatively limited strength, which makes it difficult to meet the financing needs of a large number of SME.

\section{B. The lack of guarantee assets}

On the one hand, based on the information asymmetry theory, guarantee is an important means for enterprises to obtain loans and Banks to reduce loan risks, which can solve the information asymmetry between the two sides of the loan to a certain extent. On the other hand, according to the capital management requirements of commercial Banks, due to the high risk weighting coefficient of credit assets, in order to reduce the total risk assets of Banks, the Banks have formed the situation that mortgage secured loans account for the main loan types, while the small and micro loan enterprises lack quality assets as collateral, which will lead to the inability to obtain loans. Due to the generally low asset stock, SME often lack effective mortgage and pledge. They apply for credit funds according to China's current conventional separation management system of loan examination and approval, and their loan projects are generally difficult to pass in the examination and approval process, resulting in that the credit funds cannot be lent.

\section{DEVELOPMENT STATUS OF FINANCIAL SUPPORT SYSTEM FOR SME}

Financial support is to achieve the goal and requirements of the development of specific industries. The financial industry, through the allocation of financial resources such as indirect and direct financing and insurance guarantee, actively supports and promotes the supporting objects from the supply of funds to financial services. Financial support system includes four aspects: financial organization system, financial product system, financial market system and financial supervision system [4]. At present, China's financial support system has a certain construction and development in the above aspects, but the financial support system for SME is still blank, resulting in that the financing needs of SME cannot be effectively met for a long time.

First, the government support for financing of SME is not strong. From the perspective of laws and regulations, government policies, guarantee mechanism and other aspects, the lack of laws and regulations, the release of government policies still need to be specific, and the establishment of government guarantee mechanism has not been established, etc., all of which do not effectively guarantee the financing of SME. Second, there is a large gap in the number of small and micro financial institutions. At present, internal financing is still the main financing method of SME, and the amount of financing is very limited. According to statistics, SME that rely on internal financing account for more than $60 \%$, while bank loans account for less than $30 \%$ of total external financing, and other forms of financing account for less than $10 \%$ of total financing [8]. The financing supply and demand of SME are in a state of long-term imbalance. It is imperative to effectively promote the innovation of the financial system and explore the development of financial institutions of SME. Thirdly, for the single financial product of SME, apart from a small amount of bank loans, more than $60 \%$ of the internal financing mainly relies on private loan forms such as loans from friends and relatives or other private funds, and the product types are in urgent need of innovation and enrichment[7]. At the same time, the financing guarantee mechanism for SME still has many defects and deficiencies. Lenders are often shut out because SME have no collateral or insufficient collateral. Due to the low credibility of SME, generally the guarantee company will require to pay high amount of guarantee deposit, and the loan interest rate is higher than that of large enterprises. This is a fundamental constraint on the financing of SME. In short, the current financial support system in China fails to play a supporting role in the financing of SME. Therefore, the construction of financial support system for SME is an inevitable choice to conform to the market and social and economic development.

\section{CONSTRUCTION OF FINANCIAL SUPPORT SYSTEM FOR SME IN CHINA}

\section{A. Strengthen legal construction and policy support}

Although the state council has issued relevant "notices" and "opinions" on the development of SME successively every year since 2012, the construction of laws and regulations on financing of SME and SME is still basically blank. First of all, the financing law of SME, the law of small and micro-sized financial institutions and the law of credit guarantee of SME were formulated and issued in due time to provide legal guarantee for the development of SME. Secondly, through the government's introduction of preferential policies and measures related to loans to SME of financial institutions, the risk of loans to financial institutions will be reduced and the return of loans will be increased, so as to achieve the matching ratio between risks and returns of financial institutions, which is conducive to lowering the financing threshold of SME and realizing the flow of financial resources to SME. Finally, the government can also take the initiative to invest in some SME with higher risks but higher social benefits, so as to attract the attention of the market and financial institutions to SME, and guide more financial resources to SME.

\section{B. Establish a financing and credit enhancement system for SME}

Information asymmetry and lack of adequate collateral lead to the overall low credit of SME has become the root cause of financing difficulties for SME. Therefore, strengthening the construction of credit information service and perfecting the mortgage system become the fundamental task and primary task of solving financing problems. Currently, existing credit increasing platforms in China's market include Internet financial credit increasing platform, bank credit increasing platform and government credit increasing platform[5]. Under the goal of establishing a comprehensive and complete credit enhancement system for SME, the three-party credit enhancement platform needs to strengthen information sharing and sharing, use Internet technology to carry out data mining, establish a large credit database for SME, improve information transparency, and solve the constraint of information asymmetry. At the same time, the improvement and perfection 
of the mortgage system can use the domestic and foreign successful cases for reference, and use the credit records in the big database to create the "credit capital" mortgage system, innovate the new situation of the collateral, and fundamentally solve the problem of SME' lack of collateral or insufficient collateral.

\section{Develop a multi-level guarantee system}

First, establish a government-led guarantee fund.

Premier Li Keqiang pointed out at the executive meeting of the state council on March 28, 2018 that the decision has been made to set up a national financing guarantee fund to help ease financing difficulties such as SME and "agriculture, rural areas and farmers". Meeting on the day of the decision, launched by the central government, combined with the will of the financial institutions to establish a national financing guarantee fund, not less than 60 billion yuan, the first to raise take the form of equity investment, to guarantee support the provinces (autonomous regions and municipalities) in financing guarantee business, drive the funds support SME, "three rural" and entrepreneurial innovation[3]. At the same time, strengthen the construction of social credit system. In accordance with the principle of "government support, market operation, low profit and risk control", the fund is decided and managed in a marketoriented manner. On September 26, 2018, the state financing guarantee fund co., ltd. was unveiled in Beijing, marking the official start of operation of the high-profile state financing guarantee fund, which will play a substantive role in solving the financing difficulty and expensive problem of SME. According to the introduction, the fund will mainly serve SME and "agriculture, rural areas and farmers", and gradually reach the policy requirement that the financing guarantee amount of SME shall not be less than $80 \%$, among which the financing guarantee amount of 5 million yuan and less shall not be less than $50 \%$.

Second, develop local government re-guarantee institutions.

At present, loans of SME are still required to be secured by means of mortgage or mutual guarantee, joint guarantee, etc., which will often lead to the risk of exposure due to breakage of the guarantee chain in the down period of economy. "State council on promoting the development of financing guarantee industry to speed up the opinion" pointed out that the advance of government-led complete coverage of basic implementation to guarantee agencies at the provincial level, build national financing guarantee fund, to guarantee agencies at the provincial level, facility three layers of organization system of financing guarantee agencies, effectively dispersing risk financing guarantee institutions, play a role of guarantee "stabilizer" again. We will vigorously develop governmentsupported financing guarantee institutions, with the focus on provincial and prefectural levels, with a scientific layout, and through new methods such as setting up, holding and participating in stock, develop a number of governmentsponsored financing guarantee institutions that are mainly invested by governments, have prominent business interests, standardized operations, are strong in strength, have a good reputation and have a great influence[10].
Third, we should establish a mode of cooperation in which the three parties participate.

The establishment of the financing guarantee system requires state control or equity participation, third-party commercial guarantee institutions or mutual guarantee institutions to participate in the operation, and a financing guarantee system with policy-based guarantee institutions as the main guarantee and commercial guarantee institutions to participate in the re-guarantee, so as to achieve effective and stable guarantee utility[1]. Encourage banking financial institutions according to the policy guidance and business risk control principle, and deepen the silver bear cooperation actively, promote and guarantee agencies at the provincial level for platform and cooperation between banking financial institutions, loan guarantees to the banking financial institutions in the risk of reasonable compensation, promote the establishment of sustainable silver bear business cooperation pattern. We will improve the environment for banking sector cooperation, strengthen coordination between the government and the banking sector, and jointly support the sound development of the financing and guarantee industry.

\section{Explore various financing channels}

\section{1) Make full use of banking finance}

As the main body of the financial institution system, commercial Banks still play a major role in financing. At present, China's financial market is still in the primary stage of development, and the in direct financing with the bank as the intermediary is the main form of credit. According to statistics on the website of the people's bank of China, by the end of December 2017, the stock of social financing scale in China was 174.64 trillion yuan, of which the loan scale of banking and financial institutions was 12.46 million yuan, accounting for $71.35 \%$. In that year, the balance of loans to SME of banking financial institutions nationwide was 30.74 trillion yuan, accounting for only 24.67 percent of the total outstanding loans. In 2015, the China banking regulatory commission to determine the small micro enterprise financial banking services work target (the "three no less than"), the households and "subprime loan growth and loan rate three aspects are not less than the average loan growth, households and the level of a year ago, a year ago this will further encourage financial institutions to small micro enterprise bank loans increased and improved[11].

\section{2) Guide and regulate private finance}

Originally, finance was private financing behavior, and the innovation of financial model was mostly private finance. The non-institutional output cannot obtain sufficient financial support from the formal financial institutional arrangement controlled by the government, which is the main reason for the vigorous development of private finance. In China, about half of SME and about a quarter of households choose private financing channels to obtain the capital needed for production and life. The total private finance takes a certain proportion in the scale of social financing, especially the scale of real economy financing. "Private investment is an important supporting force for stable growth, structural adjustment and employment promotion, "premier Li Keqiang stressed at the 
state council executive meeting on Aug 16, 2018. "We should firmly adhere to the basic economic system and 'two unwavering' to further promote the sound development of private investment and the private economy."[2]At present, the legal status, operation mode and supervision system of private finance can be clarified through the folk finance law to guide the construction of the legalization and regularization of private finance. At the same time, we will actively develop private financial institutions such as small loan companies, capital mutual aid agencies and village and town Banks. The development of private finance is an effective supplement to China's financial and social market development in the current period and can provide strong support for the financing of SME.

\section{3) Innovative use of Internet finance}

Internet finance is the product based on big data application, which is an effective model to break the information asymmetry between borrowers and lenders. The emergence of Internet finance has injected new blood into the traditional financial market and played a very important role in promoting the quality and efficiency of financial services, deepening financial reform, promoting financial innovation and development, expanding the opening up of the financial industry internally and externally, and building a multi-level financial system. Internet finance is characterized by low cost, high efficiency, wide coverage and rapid development, which subverts the traditional law of financing and effectively reverses the situation of financial exclusion of SME, opening a new path for solving the financing difficulties of SME. Till now, the operation mode of Internet finance is mainly divided into three categories, namely, Internet payment and settlement, Internet investment and insurance, and Internet financing. P2P, crowdfunding, and supply chain finance, etc. in Internet financing are very consistent with the financing features of SME. But at the same time, as Internet finance is in its infancy, there are still some risks in its normalization and stability. This requires the government to establish an Internet financial risk warning mechanism from a legal and policy perspective, regulate Internet finance, and provide security guarantee for Internet financing of SME.

\section{CONCLUSION}

The solution of financing problems of SME is not only a necessary condition for their own development, but also the intrinsic power of national economic and social development. The establishment of financial support system for SME can provide all-round financial support and services for SME, and provide strong guarantee for effectively solving financing problems of SME. Small micro enterprise own characteristic determines the small micro enterprise financial support system construction must play a leading role by the government, have credibility as the prerequisite of national credit guarantee system, supported by a comprehensive and fair credit rating system, formed in view of the small micro enterprise of small companies, Banks, small loan companies, small and mediumsized financial institutions, such as design for small micro enterprise financing products, and develop effective monitoring system in small micro enterprise financing risk control ability, for small micro enterprise financing.

\section{ACKNOWLEDGMENT}

Note: This project was funded by the Scientific Research Program of Shaanxi Provincial Education Department, Program NO: 17JK0974.

About the author: Li Ping nv (1981 --), a teacher and lecturer of Xi 'an Fanyi University,

Address: Xi 'an Fanyi University, TaiYiGong town, Chang 'an district, xi 'an, Shaanxi province, zip code 710105.

\section{REFERENCES}

[1] Tu Yonghong, research on Beijing's financial sustainable development under the new normal [M]. Beijing: China financial press, 2017. (In Chinese)

[2] Yan Bingzhu. Performance of CPPCC members: yan bingzhu [M]. China wenshi press, 2017. (In Chinese)

[3] Zhao Baigong. Government factors in China's currency system based on the background of transitional economy [M]. China economic press, 2016. (In Chinese)

[4] Li Lutang. Study on the theory and policy design of the market transfer mechanism of double guarantee agricultural land market [M]. Shaanxi people's publishing house, 2014. (In Chinese)

[5] Chen Guoping, editor-in-chief. Blue book of zhejiang financial development report 2014 [M]. Zhejiang university press, 2014. (In Chinese)

[6] Wang Bin. Analysis of financing difficulties of SME in the new era [J]. Financial economy, 2018.10. (In Chinese)

[7] Zhang Zhe. Development path of China's credit guarantee system in the new era [J]. Modern management science, 2018(04. (In Chinese)

[8] Zhou Lin, Wen Rui, Fu Zhiqiang. Financing solutions and countermeasures for SME from the perspective of financial mismatch [J]. Contemporary finance, 2017(01). (In Chinese)

[9] Luo Zhihua, Huang Yaguang. Research on the operating mechanism of western SME financing guarantee system: a literature review $[\mathrm{J}]$. Economic system reform, 2017(02). (In Chinese)

[10] Han Heyang, Zhou Quan, Han Junhua. Operation mechanism and path of policy-based financial support for technology-based small and micro enterprises [J]. Scientific management research, 2017 (06) . (In Chinese)

[11] http://www.pbc.gov.cn/.

[12] http://www.cbrc.gov.cn/index.html. 